\title{
FUNGSI GANDANG TASA DALAM PERAYAAN MAULUIK GADANG DI NAGARI SICINCIN KABUPATEN PADANGPARIAMAN
}

\author{
Rita Yenti \\ Guru SMA N 12 X 11 Kayutanam, Kabupaten Padang Pariaman \\ ritayenti73@yahoo.com
}

\begin{abstract}
Abstrak
Penelitian ini bertujuan membahas fungsi pertunjukan gandang tasa yang terkait dengan perayaan mauluik gadang (maulid besar) di Nagari Sicincin,Kabupaten Padang Pariaman. Deskripsi difokuskan bentuk pertunjukan dan fungsi gandang tasa dalam kontkes mauluik gadang. Mauluikgadang dimulai dari mufakat antara niniak mamak (pimpinan kaum/suku), alim ulama dan pemuka masyarakat di Kenagarian Sicincin. Pelaksanaanmauluik gadang diawali dengan kegiatan malamang, maanta paminum kopi, bajamba dan badikie. Puncak ritual mauluik gadang adalah mengarak bungo lado, yaitu berupa benda-benda arakan yang ditempeli sejumlah uang yang sering pula disebut tabuik. Bungo lado/tabuik diarak dari berbagai arah yang berasal dari korong (kampung) yang ada di Nagari Sicincin ke Masjid Raya Nagari Sicincin/ masjid utama nagari yang selalu diiringi oleh gandang tasauntuk membangun suasana menjadi meriah.
\end{abstract}

Kata kunci :mauluik gadang, gandang tasa, fungsi,bungo lado, tabuik.

\begin{abstract}
This research is aimed to discuss the function of gandang tasa performance which is performed in Mauluik Gadang event (Maulid Besar) in Sicincin District, Padang Pariaman Regency. The description is focused on how Gandang Tasa performs in Mauluik Gadang context. Mauluik Gadang event starts from decision-making consensus led by all the chief of Adat society (Ninik Mamak) as tribe leaders, scholar of Islam, elite figure of society in Sicincin District. In the beginning of this event, there are Malamang activity, serving meals, variety of local authentic foods and prays held together as celebration. The main ritual of Mauluik Gadang is showing Bungo Lado, hand-made trees which are decorated some stick money. These tresses are also called Tabuik. Bungo Lado/tabuik appears in street parade from any part of villages in Sicincin District to the main mosque/Masjid Raya Nagari Sicincin. Gandang Tasa has function to accompany the street parade gloriously and entertained.
\end{abstract}

Keywords : mauluik gadang, gandang tasa, function, bungo lado, tabuik 


\section{PENDAHULUAN}

Perayaan hari kelahiran Nabi atau maulid Nabi Muhammad SAW dilaksanakan dengan berbagai cara yang spesifik di berbagai daerah di Sumatra Barat. Salah satunya adalah perayaan maulid Nabi Muhammad SAW yang dilaksanakan di Nagari Sicincin, Kecamatan 2 X 11 Enam Lingkung, Kabupaten Padang Pariaman, Sumatera Barat. Maulid Nabi di Nagari Sicincin secara spesifik ada yang disebut mauluik gadang, yaitu perayaan maulidyang dilakukan secara besar, megah, dan meriah oleh seluruh komponen dan lapisan masyarakat Nagari Sicincin. Mauluik gadang hanya dilakukan sekali dalam dua tahun. Waktu sela di antara dua tahun itu, tetap dilakukan ritual mauluik yang dinamakan mauluik ketek (maulid kecil) yang hanya diadakan di setiap korong atau kampung yang ada di Nagari Sicincin secara terpisah dengan waktu yang berbeda pula.

Setiap perayaan mauluik gadang di Nagari Sicincin, bagian ritual yang selalu dihadirkan adalah mengarak bungo lado, yaitu berupa benda-benda arakan yang ditempeli sejumlah uang pada ranting kayu dan benda-benda lainnya. Arakarakan bungo lado ini lebih umum di Nagari Sicincin disebut tabuik.Bungo lado/tabuik diarak dari berbagai arah yang berasal dari korong (kampung) yang ada di Nagari Sicincin ke masjid utama nagari yang selalu diiringi oleh gandang tasa. Pengertian tabuik pada perayaan mauluik gadang di Nagari Sicincin tidak sama dengan pengertian tabuik di Kota Pariaman. Pengertian tabuik di Kota Pariaman adalah artefak budaya setinggi 10-12 meter yang diarak pada perayaan Tabuik setiap bulan Muharam (Asril,
2013: 310; lihat juga Febrina, 2012:1-2).

Adapun pengertian tabuik di Sicincin, menurut Romy Junaidi Sidi Brahim salah seorang tokoh masyarakat Nagari Sicincin sebagaimana dikutip oleh Asril dkk., menyebutkan:

"Tabuik refers to the objects that are carried in the procession to help create an atmosphere of excitement at the time of mauluik. Originally, the tabuik consisted of objects made from twigs that were decorated with coloured paper. Banknotes would be fastened to each twig and carried to the mosque as a way of raising money to rebuild the mosque. These coloured twigs, decorated with banknotes, were formerly known as bungolado (chili flowers, the flowers being represented by the paper money), but in subsequent developments various other kinds of attributes have begun to be used, which are quite different from the original twigs and paper money, and they are shaken and swung around in a similar way to the tabuik in Pariaman. In the procession, the gandang tasa often plays the same piece that is performed during the Tabuik ritual, and for this reason, the collection of objects carried in the procession has become known as the tabuik" (Asril, et al., 2018: 18).

("Tabuik adalah benda-benda yang diarak untuk mendukung suasana gembira pada saat mauluik. Awalnya tabuik berasal dari benda-benda yang terbuat dari ranting-ranting kayu kemudian dihiasi dengan kertas warna-warni. Pada setiap ranting itu ditempeli dengan sejumlah uang 
kertas ribuan untuk diarak ke masjid dalam rangka mengumpulkan dana untuk pembangunan masjid. Rantingranting kayu berwarna-warni yang ditempeli uang kertas itu pun pada mulanya disebut bungo lado (bunga cabe, uang kertas menjadi bunga), tetapi kemudian berkembang menjadi berbagai bentuk atribut yang jauh dari bentuk asalnya, dan cara membawanya pun dihoyak dan digoyangkan-goyangkan sehingga mirip dengan cara menghoyak tabuik di Pariaman. Dalam mengaraknya digunakan pula gandang tasa dengan lagu yang sering dimainkan pada ritual Tabuik, sehingga benda-benda itu disebutlah tabuik.”)

Jadi, pengertian tabuik oleh masyarakat Sicincin tidak memiliki kaitan langsung dengan peristiwa dan upacara Tabuik di Pariaman. Akan tetapi, ada beberapa prinsip yang diambil dari semangat yang ada pada Tabuik di Kota Pariaman. Misalnya, cara menghoyak, menggunakan gandang tasa, lagu yang dimainkan meniru gaya yang dilakukan dalam Tabuik Pariaman, tetapi dengan semangat yang berbeda.

Gandang tasa berfungsi untuk membangun suasana menjadi meriah. Prosesi ini dilakukan secara bergantian antara satu korong dengan korong lainnya dan kadang-kadang disela pula oleh partisipan para perantau Sicincin yang turut memberikan sumbangan bungo lado. Prosesi itu akan berlangsung sejak siang hingga sore hari. Prosesi bungo lado yang diiringi oleh gandang tasa yang menghadirkan suara keras dan bertalu- talu sepanjang jalan yang dilaluinya menjadi daya tarik khusus bagi masyarakat Sicincin dan pengunjung lainnya. Mengarak bungo lado menjadi puncak perayaan mauluik gadang di Nagari Sicincin.

Berdasarkan pengamatan terhadap fungsi gandang tasa khususnya pada saat mengarak bungo lado menjadi peristiwa yang unik dan menjadi daya tarik bagi penulis uantuk membahasnya. Apa fungsi, makna, dan nilai gandang tasa dalam perayaan mauluik gadang di Nagari Sicincin? Tujuan penelitian ini adalah untuk mendiskripsikan dan menganalisis fungsi, makna, dan nilai gandang tasa dalam perayaanmauluik gadang di Nagari Sicincin, Kabupaten Padang Pariaman.

\section{HASIL DAN PEMBAHASAN}

\section{A. Pelaksanaan Mauluik Gandang di Nagari Sicincin}

Setiap pelaksanaan perayaan mauluik gadang di Nagari Sicincin ada beberapa tahap pekerjaan yang dilakukan secara bersama oleh unsur-unsur tokoh masyarakat dan masyarakat dalam Nagari Sicincin.

\section{Persiapan}

Sebelum upacara mauluik gadang dilangsungkan, diadakan musyawarah di Masjid Raya Nagari Sicincin. Musyawarah dihadiri oleh pemuka masyarakat terdiri dari niniak mamak, alim ulama, dan pemuka masyarakat lainnya di Nagari Sicincin yang terdiri dari empat korong, yaitu: Pauh, Bari, Sicincin, dan Ladang laweh. Dalam Nagari Sicincin terdapat tujuh suku, yaitu: koto, sikumbang, guci, pinyalai, jambak, tanjuang dan mandailiang Tujuan dari musyawarah 
tersebut untuk mencari kesepakatan badikie.

kapan akan dilangsungkannya acara perayaan mauluik gadang. Menjelang tanggal 12 Rabbiul Awal masyarakat masing-masing suku/kaum melangsungkan acara manyonsong bulan di surau kaum masing-masing sesuai dengan jadwal yang telah ditetapkan bersama. Pelaksanaannya dilakukan secara bergantian di setiap malamnya. Beberapa hari menjelang hari mauluik gadang masyarakat diminta untuk mengadakan gotong royong membersihkan masjid dan pekarangan disekitarnya. Selanjutnya satu hari menjelang upacara berlangsung, tepatnya pada hari jumát malam, masyarakat bekerjasama untuk membuat ruang untuk memajangkan paminum kopi yang merupakan perwakilan dari masingmasing kaum, serta sekaligus tempat tersebut berfungsi untuk tempat duduk urang siak selama badikie. (Febrina, 2012: 45-46).

\section{Pelaksanaan}

Mauluik gadang dilaksanakan oleh seluruh masyarakat Nagari Sicincin yang berlangsung selama dua hari. Waktu pelaksanaannya dilangsungkan pada hari Sabtu dan Minggu. Adakalanya waktu yang dipilih itu bertepatan dengan tanggal 12 Rabiul Awal, ada juga yang dilangsungkan beberapa hari setelah itu, bahkan beberapa minggu, sesuai dengan hasil kesepakatan yang dilakukan oleh para pemuka masyarakat dan unsur yang berwenang dalam mayarakat Nagari Sicincin.

Menurut Febrina (2012: 47-54), kegiatan yang dilakukan dalam perayaan mauluik (mauluik gadang) di Nagari Sicincin sebagai bagian ritual, yaitu: malamang, mahanta kue, bajamba, dan

\subsection{Malamang}

Malamang atau memasak lemang sudah menjadi suatu tradisi bagi masyarakat Nagari Sicincin. Begitu juga halnya dalam upacara mauluik gadang, masyarakat menyemarakkan dengan memasak lamang di rumah masingmasing. Proses pembuatan lamang atau malamang biasanya dilakukan sejak pukul 16.00 sore, dimulai dengan mempersiapkan buluah (sejenis talang), daun pisang, santan, merendam pulut, dan lain-lain. Lamang mulai dibakar sekitar pukul 06.00 pagi besok harinya. Lamang dibakar dengan memgunakan kayu, tempurung, dan sabut kelapa, yang sudah dipersiapkan beberapa hari sbelumnya. Kegiatan malamang biasanya baru selesai sekitar pukul 10.00-11.00 siang.

\subsection{Mahanta kue (paminum kopi)}

Mahanta kue adalah aktivitas mengantarkan kue dan jenis makanan lainnya seperti minuman kopi ke masjid yang dilakukan oleh para anggota keluarga masyarakat Nagari Sicincin sebagai bentuk partisipasi dan eforia untuk memeriahkan perayaan mauluik. Hal itu sudah menjadi bagian tradisi perayaan mauluik gadang di Nagari Sicincin, yaitu setiap kelompok suku/kaum memperagakan bawaan mereka berupa kue-kue dan aneka jenis makanan-makanan kecil yang dibawa ke masjid. Disini jelas terlihat bahwa mereka sangat memprioritaskan segi kuantitas dan kualitas dari bawaan tersebut. Bahkan, secara tidak langsung pada saat suasana ini terlihat semacam adanya perlombaan dari masing-masing kaum/suku. Mereka menata seindah mungkin bawaan dari kaum/suku mereka masing-masing. Tujuannya adalah agar bawaan mereka 
dinilai sebagai tampilan terbaik oleh orang-orang yang melihat nantinya.

\subsection{Bajamba}

Jamba adalah berbagai jenis laukpauk seperti ikan, ayam, telur beserta nasi yang diletakkan dan ditata di atas dulang, yang ditutupi dengan tudung saji dan kain dalamak di atasnya. Pada hari terakhir mauluik gadang di Nagari Sicincin, masyarakat, khususnya kaum ibu, membawa jamba dan beserta lamang ke masjid. Aktivitas membawa jamba tidaklah merupakan kewajiban, masyarakat melakukannya secara suka rela. Jamba diperuntukkan kepada urang siak, yaitu kelompok alim ulama tradisional, seperti labai, katik dan sebagainya, dan anggota masyarakat (khususnya laki-laki) yang telah membawa arak-arakan tabuik yang diiringi oleh musik gandang tasa dari korong masing-masing.

\subsection{Badikie}

Pembacaan dzikir atau badikie sesungguhnya adalah merupakan inti dari upacara peringatan Maulud Nabi. Ini adalah untuk memperingati hari kelahiran Nabi Muhammad SAW, yang diwujudkan melalui pembacaan dikie mauluik, yaitu kitab sastra Arab Syaraful Anaam yang mengisahkan tentang peristiwa kelahiran dan keutamaan sifat Nabi Muhammad SAW beserta perjuangannya dengan para sahabatsahabatnya dalam menegakkan agama Islam. Dalam pembacaan dikie mauluik tersebut sesungguhnya dapat dilihat berbagai bentuk dan unsur seni yang terdapat didalamnya, seperti seni sastra dan seni suara. Dikie adalah sebagai ungkapan rasa terima kasih dan rasa syukur terhadap Allah SWT yang telah melimpahkan rahmat dan hidayah-Nya kepada umat manusia.

Badikie dalam perayaan mauluik gadang di Nagari Sicincin dilakukan oleh urang siak dari empat korong yang ada di Nagari Sicincin, dan biasanya ada juga tukang dikie yang diundang dari nagari lain di sekitar Kecamatan $2 \mathrm{X} 11$ Enam Lingkung dan Kecamatan VII Koto Sungai Sariak. Badikie dimulai sekitar pukul 22.00 atau 23.0o dan berlangsung sampai menjelang subuh. Setelah istirahat beberapa jam, sekitar pukul o9.0o dikie kembali dilanjutkan sampai menjelang waktu salat Ashar.

\section{B. Pertunjukan Gandang Tasa dalam Perayaan Mauluik Gadang}

Aspek pertunjukan yaitu, hal-hal yang berkaitan dengan bagimana penyajian kesenian itu sendiri dalam konteks upacaranya, yang teridiri dari bagaimana bentuk pertunjukan, tempat pertunjukan, waktu pertunjukan, pakaian atau kostum pemain serta lagu-lagu yang dimainkan dalam pertunjukan tersebut. Adapun aspek pertunjukan musik gandang tasa dalam perayaan mauluik gadang di Nagari Sicincin adalah sebagai berikut.

\section{Bentuk Pertunjukan}

Gandang tasa dalam konteks perayaan mauluik gadang di Nagari Sicincin dimainkan sambil berdiri dan berjalan dari masing-masing korong menuju masjid tempat berlangsungnya upacara. Gandang tasa dimainkan dengan cara disandangkan dengan tali pada bahu atau pundak masing-masing pemain. Adapun jumlah instrumennya adalah terdiri dari satu buah tasa dan 5-7 buah gandang. Pertunjukan diawali oleh tasa 
yang berfungsi sebagai komando, setelah itu dilanjutkan oleh gandang. Kedua instrumen ini dimainkan dengan teknik interlocking antara gandang dengan tasa. Di sini pemain tasa harus bisa memberi improvisasi-improvisasi yang berfungsi sebagai paningkah sehingga permainan semakin enak didengar.

Adapun posisi pemain gandang tasadalam prosesi ini yakni, pemain gandang tasa berada di belakang rombongan yang membawa tabuik. Disepanjang jalan gandang tasa terus dimainkan dengan memainkan pola atau lagu yang dinamakan oleh masyarakat setempat dengan pola atau lagu oyak tabuik. Gandang tasa dimainkan secara non stop hingga sampai ke masjid, dengan tempo permainan makin lama semakin cepat. Gandang tasa yang memiliki karakter suara keras, dinamis, dan enerjik sehingga sering mengundang perhatian orang-orang yang berada di sekelilingnya dan juga akan semakin meningkatkan semangat dan antusias masyarakat (Febrina, 2012:74-75).

\section{Waktu Pertunjukan}

Waktu pertunjukan musik gandang tasa dalam perayaan mauluik gadang di Nagari Sicincin adalah pada hari kedua (terakhir) berlangsungnya upacara. Mulai dari sekitar pukul 10.00 para pemuda yang dipimpin oleh kapalo mudo mereka sudah mulai memainkan musik gandang tasadi tepi jalan raya atau jalan utama di masing-masing korong yang ada di Nagari Sicincin. Ketika gandang tasa dimainkan, para pemuda yang lainnya meminta sumbangan kepada setiap pengendara yang melewati jalan tersebut.

Sekitar pukul 13.00 adalah waktunya untuk meminta sumbangan ke warung-warung serta ke rumah-rumah penduduk yang juga diiringi dengan bunyibunyian gandang tasa sambil berjalan ke seluruh penjuru kampung. Adapun waktu yang sangat ditunggu-tunggu oleh masyarakat adalah pada sore hari sekitar pukul 16.00 atau sesudah salat Ashar, dilakukan prosesi maarak Tabuik ke masjid. Masing-masing rombongan dari masing-masing korong memainkan gandang tasa di sepanjang jalan hingga sampai ke masjid. Pertunjukan gandang tasa sangat semarak berlangsung di halaman masjid, yang biasanya baru akan berakhir sekitar pukul 18.00 sore.

\section{Tempat Pertunjukan}

Tempat pertunjukan gandang tasa adalah pada lapangan atau arena terbuka yang bertempat di dua tempat yakni: di tepi jalan utama di masing-masing korong dan di sepanjang jalan dari masing-masing korong sambil membawa arakan Tabuik ke masjid. Ada dua jalan masuk yang selalu dipakai untuk masuk menuju masjid, yaitu dari arah Pasar Sicincin dan di Korong Pauh. Tempat pertunjukan terakhir adalah di halaman Masjid Raya Nagari Sicincin.

\section{Lagu-Lagu yang Dimainkan}

Menurut Asril Muchtar (2005) dan Asril (2002): "Secara musikal gandang tasa termasuk ke dalam musik perkusi yang bersifat ritmik tanpa melodi. Instruman-instrumen yang digunakan adalah gendang bermuka dua (doubleheaded cylindrical drum) dan tasa jenis bermuka satu yang berbentuk seperti kuali (single-headed, vessel drum). Setiap instrumen dimainkan oleh satu orang pemain yaitu: satu orang pemain tasa dan selebihnya gandang. Gandang berfungsi sebagai pembawa ritme yang cenderung konstan, terutama pada saat memainkan 
pola ritme pendek-pendek, baik dalam permainan interlocking maupun dalam bentuk serempak. Sementara tasa difungsikan sebagai komando pembawa ritme, seperti pada saat mengawali pertunjukan, merubah atau mengalihkan pola ritme, dan mengakhiri lagu. Ritmeritme yang dimainkan melalui tasa lebih variatif dan sangat dimungkinkan untuk melakukan improvisasi-improvisasi."

Menurut Febrina (2012:79-80)" "Komposisi musiknya dibangun dari permainan interlocking ritme antar kedua instrumen tersebut (gandang dan tasa), sehingga terjadi penjalinan pola ritme di antara masing-masing gandang dan tasa itu. Adapun jenis lagu-lagu gandang tasa yang sering dimainkan di Nagari Sicincin adalah jenis lagu-lagu yang menyajikan pola ritme pendek-pendek. Garapan musiknya dilakukan berulang-ulang dalam waktu yang relatif lama, sehingga cenderung monoton. Lagu yang dimainkan mereka sebut dengan lagu Oyak Tabuik. Lagu Oyak Tabuik yang dimainkan dalam konteks ini memang tidak sama dengan lagu Oyak Tabuik yang terdapat di Pariaman. Pola pukulan yang dimainkan dalam lagu Oyak Tabuik yang dimainkan dalam prosesi arakarakan Tabuik dalam perayaan mauluik gadang di Nagari Sicincin sangat sederhana dan cenderung monoton. Namun yang paling menonjol atau yang lebih dominan dalam permainan tersebut adalah instrumen tasa yang membawa tempo permainan dan juga memberi improvisasi-improvisasi, sedangkan gandang hanya memberikan aksentuasi dengan pola yang sederhana. Kecenderungan mereka lebih sering memainkan pada beat, dengan isian atau improvisasi yang diberi oleh pemain tasa, sehingga jalinan antara kedua instrumen tersebut tetap enak didengar."

Apabila dibandingkan dengan lagu Oyak Tabuik yang terdapat di Kota Pariaman, tampaknya lagu oyak Tabuik yang dimainkan pada perayaan mauluik gadang di Nagari Sicincin tersebut memang sederhana. Lagu Oyak Tabuik di Pariaman dimainkan dengan teknik interlocking. Selain dari tasa, salah satu dari gandang pada bagian-bagian tertentu bertugas memainkan pola yang berbeda dari gandang yang lainnya sehingga terkesan jalinan bunyi yang bertingkah (interlocking) (Febrina, 2012:82-83).

Pukulan pola ritme yang sederhana dan terkesan monoton itu, namun dapat membangkitkan semangat masyarakat dalam mengiringi prosesi tersebut. Pola ritme tasa mengisi pola ritme gandang dengan pola yang jarang, akan tetapi semakin lama pola ritme tasa semakin rapat, kemudian mengisi dengan pola yang agak jarang. Permainan seperti ini terus berulang mengiringi arak-arakan tabuik dari masing-masing korong menuju masjid.

\section{Arak-arakan Bungo Lado/tabuik}

Arak-arakan bungo lado ataua batabuik dalam perayaan mauluik gadang merupakan salah satu tradisi masyarakat Nagari Sicincin. Arak-arakan yang dilakukan oleh masyarakat Nagari Sicincin dalam rangka Maulid Nabi ini artinya berbesar hati (bersenang hati menyambut hari kelahiran Nabi Muhammad SAW). Menurut Tuanku Nan Cantiak: "Tradisi mengarak bungo lado telah dilakukan secara turun temurun sejak zaman Belanda sampai sekarang di surau yang beratap ijuk yang berdiri tidak jauh dari Masjid Raya Nagari Sicincin"(wawancara pada 10 Desember 2018 di Pauah Sicincin). Arak-arakan bungo lado dimulai 
dari korong masing-masing dan berakhir di Masjid Raya Nagari Sicincin. Uang yang terdapat pada bungo lado uang mulai dari sepuluh ribu sampai uang seratus ribu diserahkan kepada panitia mauluik gadang yang berada Masjid Raya Nagari Sicincin.

Menurut Zuefa salah seorang panitia mauluik gadang mengatakan: "Maulid batabuik dilakukan sekali dua tahun. Artinya, pelaksanaannya digelar secara bergantian. Kalau tahun ini di Surau Baru Bari, maulid tahun depan di Masjid Raya Nagari Sicincin yang terletak di Korong Pauah. Ini tradisi lama yang tidak diketahui kapan dimulainya. Tampaknya masyarakat punya kreatif sendiri. Mereka berbuat banyak untuk pembangunan surau, melalui hoyak Tabuik."(Zuefa, wawancara pada Kamis, 13 Desember 2018 di Pasar Sicincin)

Panitia lainnya, Hasan Basri menyebutkan kalau setiap maulid lumayan besar dapat uang. Yang paling banyak itu, ya, dari batabuik ini. Setelah adanya kesepakan, bahwa tahun ini dilakukan mauluik gadang, maka sehari sebelum acara pemuda jorong dimaksud mencari dana, dengan minta sumbangan di setiap persimpangan jalan, dan ditambah dengan sumbangan rang sumando (orang semenda) serta anggota pemuda. (Hasan Basari, wawancara pada Kamis, 13 Desember 2018 di Pasar Sicincin).

Arak-arakan Korong Bari dimulai pada pukul 14.00. Mereka melakukan arak-arakan di sepanjang jalan yang ada di Korong Bari hingga menuju masjid. Akan tetapi, mereka ada kalanya melewati jalan utama menuju arah terminal Sicincin. Rombongan prosesi Bari membawa bungo lado dari ranting kayu yang diiringi dengan gandang tasa.

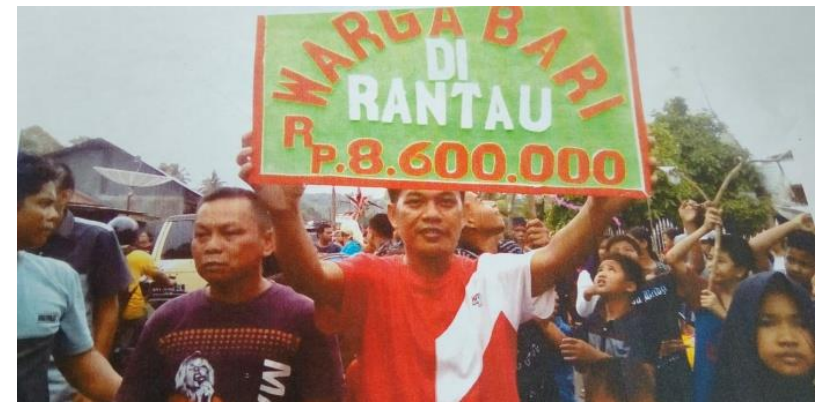

Gambar 1.

Arak-arakan bungo ladodari Korong Bari (foto: Rita, Desember 2018).

Arak-arakan Korong Sicincin terpusat di terminal Sicincin. Bentuk bungo lado/tabuik yang diarak berbentuk hiasan-hiasan dari hasil tani. Korong Bari dan Korong Sicincin bertemu di terminal melakukan atraksi arak-arakan gandang tasa dan tabuik. Atraksinya berupa berjoget atau berjingkrak mengikuti irama gandang tasa sambil melontarkan kata oyak, oyak, oyak. Selanjutnya Korong Bari dan Korong Sicincin menuju Masjid Raya Nagari Sicincin yang terletak di Korong Pauh. Sementara arak-arakan bungo lado/tabuik dari Korong Ladang Laweh berupa seekor burung terbang.

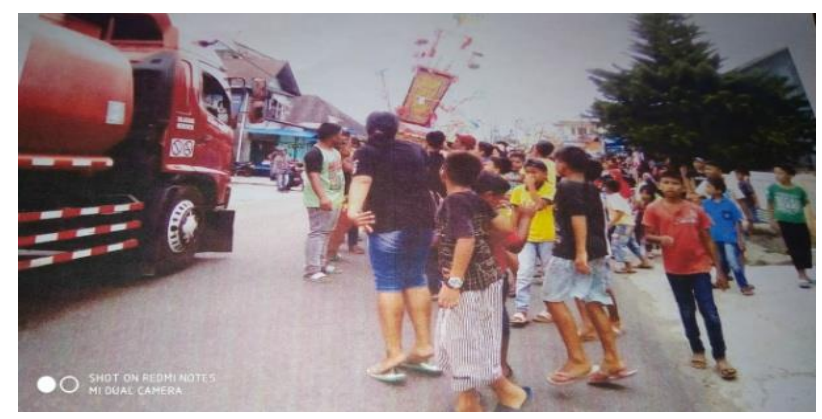

Gambar 2.

Arak-arakan tabuik di pinggir jalan raya. (foto: Rita, Desember 2018).

Adapun arak-arakan bungo lado/tabuik dari Korong Pauh yang berada di belakang Masjid Raya Nagari Sicincin membawa gambar kerbau hitam yang melambangkan keberanian. Semua arakarakan bungo lado/tabuik dari korong itu 
diiringi oleh kelompok gadang tasa dari korong mereka masing-masing.

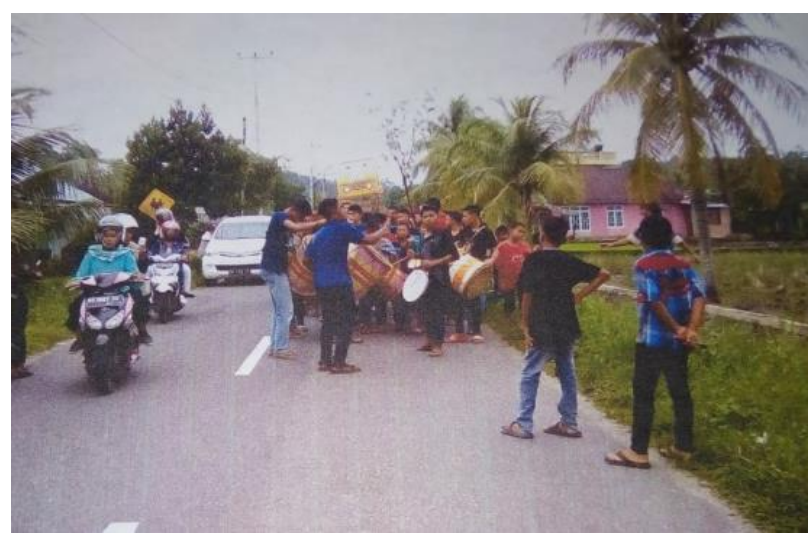

Gambar 3.

Arak-arakan bungo lado diiringi gandangtasa.

(foto: Rita, Desember 2018).

Uang pada bungo lado berasal dari sumbangan dari perantau Nagari Sincin, dan ditambahkan dengan sumbangan masyarakat setempat. Uang yang terkumpul akan digunakan untuk pembangunan Masjid Raya atau pembangunan lainnya. Tradisi mauluik gadang dan arak-arakan oyak tabuik yang diiringi oleh gandang tasa telah dilakukan secara turun temurun sejak dahulu sampai sekarang ini.

Hal-hal unik sering terjadi ketika mengarak bungo lado biasanya ada peserta yang pingsan, tidak sadarkan diri (seperti orang mabuk), bahkan terkadang ada juga mereka yang sampai berkelahi. Mereka mengalami hal itu karena adanya gandang tasa sebagai musik pengiring prosesi yang memberikan semangat kepada mereka. Sebagaimana dinyatakan oleh Asril, dkk., berikut ini.

When asked why they could experience a state of trance, or near trance, or flow, the participants of the procession all answered that the sound of the beat and rhythms of the gendang in the gandang tasa ensemble being played at a fast tempo and with a loud volume affected their emotions and caused them to lose control to the point where they lost consciousness. (Asril, et al., 2018:20)

(Situasi trance dan mendekati trance atau flow yang dialami oleh para peserta prosesi, ketika dikonfirmasi, mengapa mereka trance atau mendekati trance? Semuanya sepakat menjawab bahwa pengaruh bunyi hentakan dan ritme gendang dari gandang tasa dalam tempo cepat dan suara keras sangat cepat mempengaruhi emosi mereka menjadi tak terkendali hingga tak sadarkan diri.)

Kondisi ini terjadi biasanya diawali pada saat rombongan prosesi akan mendekati masjid, pemain tasa meningkatkan tempo permainan semakin cepat, dengan isian tasa yang semakin rapat. Ketika telah sampai di masjid, tempo permainan gandang tasa berada pada kecepatan maksimal sampai akhirnya berdampak kepada para peserta prosesi menjadi tidak sadarkan diri atau terjadi ketegangan emosional. Namun apabila hal ini terjadi, maka segera diselesaikan dan didamaikan kembali oleh para pemuka masyarakat seperti kapalo mudo, urang tuo, atau niniak mamak sampai kedua belah pihak tersebut berdamai kembali. 


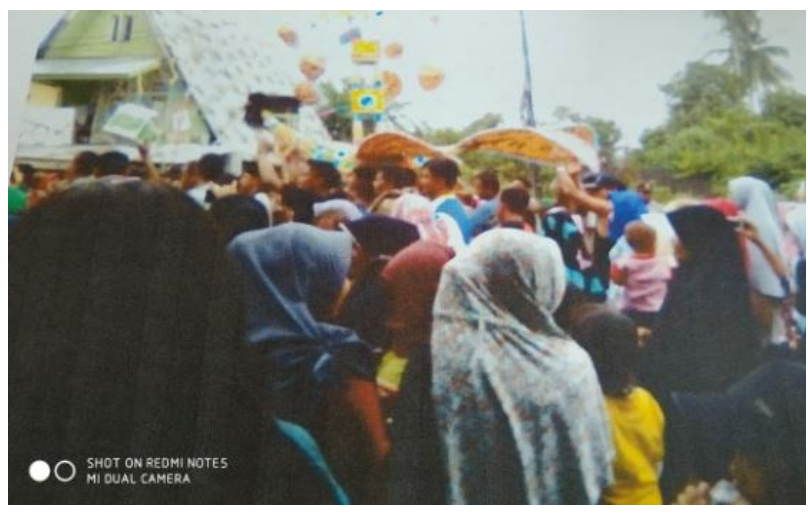

Gambar 4 .

Suasana arak-arakan tabuik dalam perayaan mauluik gadang

(foto: Rita, Desember 2018)

Dari keempat rombongan prosesi Korong itu, diperbolehkan masuk satu persatu ke arena masjid. Setiap rombongan diberi durasi pertunjukan sekitar sepuluh menit. Saat pertunjukan berlangsung ada saja pemain gandang tasa yang kehilangan kesadaran atau kesurupan. Pertunjukan gandang tasadalam arena masjid, antara penonton dan pemain menyatu, hingga tidak ada batas atau jarak antara mereka. Selesai pertunjukan gandang tasa, seluruh pemain yang berasal dari ke empat korong beristirahat di masjid sambil makan bajamba atau bersama yang telah disediakan masing-masing korong.

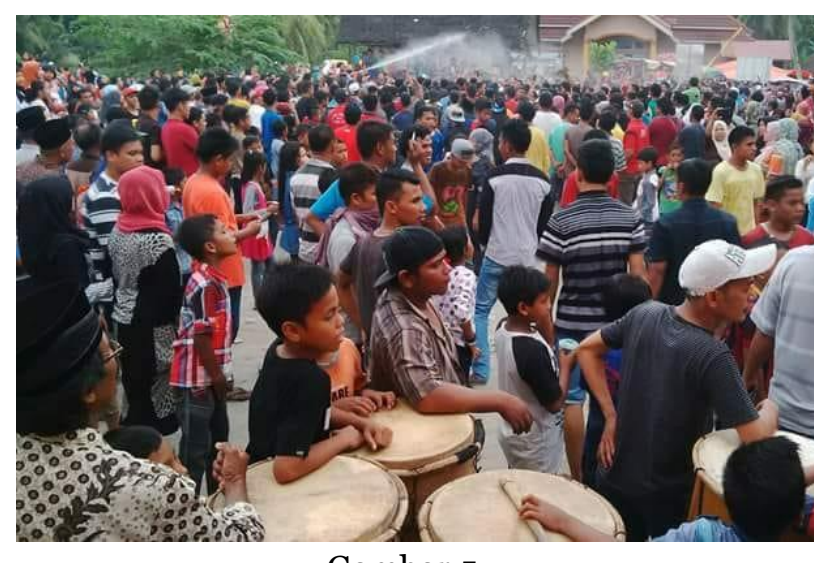

Gambar 5 .

Suasana peserta prosesi dengan penonton membaur menjadi satu di halaman masjid. (foto: Rita, Desember 2018)

\section{Fungsi Gandang Tasa dalam Mauluik Gadang}

Segala aktivitas kebudayaan itu sebenarnya bermaksud memuaskan suatu rangkaian dari sejumlah kebutuhan naluri manusia pendukung kebudayaan tersebut yang berhubungan dengan kehidupannya. Kesenian sebagi contoh dari salah satu unsur kebudayaan, terjadi karena mulamula manusia ingin memuaskan kebutuhan nalurinya terhadap keindahan. Gandang tasa hadir dalam berbagai kegiatan upacara ada yang kehadiranya hanyalah sebagai pelengkap upacara atau hanya sebagai hiburan saja, namun ada juga yang sangat memberi arti, bahkan menjadi bagian penting terhadap kelangsungan upacara tersebut.

Sebagaimana halnya dalam ritual Tabuik Pariaman, kehadiran ensambel gandang tasa pada ritus-ritus tertentu dalam upacara tersebut menjadi bagian penting bagi masyarakat Pariaman dalam kelangsungan tradisi ritual tersebut. Selain itu misalnya sebagai pengiring tari galombang dalam upacara batagak penghulu, kehadiran musik gandang tasa di sini juga sangat berperan penting sebagai musik iringan tarian tersebut. (Asril, 2005).

Suatu bentuk kesenian akan hadir di tengah-tengah masyarakat setempat jika memiliki fungsi tertentu dalam masyarakat. Kehadiran bentuk seni tersebut dapat berfungsi, baik yang berkaitan dengan kepentingan ritual maupun yang hanya bersifat kemasyarakatan saja. Suatu penyajian karya seni tentunya tidak hanya dipandang dari segi bentuknya saja, akan tetapi juga 
dilihat dari aspek fungsi penyajian mauluik gadang di Nagari Sicincin, kesenian itu dalam kehidupan difungsikan sebagai hiburan bagi masyarakatnya. Oleh karena hal ini masyarakat, khususnya bagi masyarakat menyangkut hubungan timbal balik setempat.

antara subjek dan objek serta bagaimana efek musikal terhadap pemiliknya.

Untuk membahas fungsi gandang tasa dalam perayaan mauluik gadang di Nagari Sicincin digunakan teori fungsi musik menurut Merriam. Menurut Merriam, ada sepuluh fungsi musik dalam konteks kehidupan suatu masyarakat, yaitu: (1) fungsi ekspresi, (2) fungsi penghayatan estetis, (3) fungsi hiburan, (4) fungsi komunikasi, (5) fungsi perlambang, (6) fungsi reaksi jasmani, (7) fungsi yang berkaitan dengan normanorma sosial, (8) fungsi pengesahan lembaga sosial dan upacara agama, (9) fungsi kesinabungan, dan (10) fungsi pengintegrasian masyarakat (Merriam, 1964). Berdasarkan kondisi yang ditemui dalam penelitian di lapangan, fungsi gandang tasa dalam konteks mauluik gadang di Nagari Sicincin hanya mencakup fungsi hiburan, fungsi ekspresi, dan fungsi pengintegrasian masyarakat.

\section{Fungsi Hiburan}

Kesenian dan hiburan berkembang tergantung pada keadaan dan lingkungan masyarakat, semakin tinggi kreativitas kelompok suatu masyarakat maka semakin tinggi karya seni yang dihasilkan. Setiap karya seni tidak terlepas dari ungkapan dan ekspresi manusia yang dilahirkan hanya semata-mata sebagai penenang jiwa baik bagi pelaku seni itu sendiri maupun bagi penikmatnya. Hal ini berarti bahwa seni adalah sebagai penghibur bagi manusia.Begitu juga halnya dengan gandang tasa yang digunaan dalam arak-arakan tabuik sebagai bagian dari tradisi perayaan

\section{Fungsi Ekspresi}

Penyajian gandang tasa ketika mengiringi arak-arakan bungo lado/tabuik dari masing-masing korong menuju masjid, berbagai ekspresi yang terjadi pada pemain gandang tasa dan orang-orang yang ikut serta mengiringi prosesi tersebut. Sebagaimana yang peneliti saksikan pada setiap prosesi itu beragam tingkah laku dalam mengekspresikan kegembiraan mereka;ada yang berteriakteriak hoyak..! hoyak...! sambil melompat-lompat. Selain itu, ada juga peserta prosesi yang tidak sadarkan diri atau trance karena terlalu brsemangat dan terhanyut dengan suara gandang tasa.

\section{Fungsi Pengintegrasian Masyarakat}

Dari kenyataan fungsi musik sebagai media komunikasi terlihatlah bahwa musik juga merupakan wadah untuk berkumpulnya para anggota masyarakat dan mengajak warga tersebut untuk turut serta berkreativitas, serta meningkatkan rasa akan pentingnya mereka sebagai kesatuan kelompok. Sebagaimana menurut pengamatan penulis gandang tasa disini berfungsi sebagai pengintegrasian masyarakat yang berasal dari masing-masing korong dan juga masyarakat Nagari Sicincin umumnya, mereka berkumpul dalam kebersamaan karena ada perayaan mauluik gadang.

Fungsi ini tampak dalam prosesi arak-arakan bungo lado/tabuik. Masyarakat hanya dengan mendengarkan suara gandang tasa dari jauh saja, mereka 
akan tahu bahwa, bungo lado/tabuik akan segera diarak ke masjid. Masyarakat akan berbondong-bondong untuk menyaksikan bahkan, ada yang langsung bergabung dan mengikuti arakan tersebut hingga sampai ke masjid.Disana akan bertemu seluruh lapisan masyarakat Nagari Sicincin, tentunya masyarakat dari antar suku/kaum, antar usia, jenis kelamin dan status sosial.

\section{KESIMPULAN}

Perayaan mauluik gadang di Nagari Sicincin Kabupaten Padang Pariaman yang dilakukan selama dua hari yang diisi dengan berbagai kegiatan yang bersifat ritual, baik ditujukan secara khusus memuliakan Nabi Muhammad melalui ritual badikie, maupun ritual yang muncul sebagai bentuk eforia dan kegembiraan masyarakat dalam memperingati maulid. Ritual yang bersifat kegembiraan lahir melalui perilaku arak-arakan membawa bungo lado atau tabuik yang diarak dari korong masing-masing menuju Masjid Raya Nagari Sicincin. Setiap arak-arakan bungo lado/tabuik diiringi dengan gandang tasa. Musik perkusi iniberfungsi memeriahkan suasana arak-arakan menjadi bersemangat dan gembira. Secara keseluruhan arak-arakan yang diiirngi oleh gandang tasa berfungsi sebagai ekspresi kegembiraan, fungsi hiburan, dan berfungsi untuk mengintegrasikan seluruh lapisan masyarakat Nagari Sicincin dalam suatu ritual mauluik gadang yang dilakukan dan dirayakan secara bersama.

\section{DAFTAR PUSTAKA}

Asril, 2015. "Peran Gandang Tasa dalam Pertunjukan Tabuik. Dalam Jurnal Humaniora, Vol. 27, No. 01 Februari.

. 2015. "Perayaan Tabuik dan Tabot: Jejak Ritual Keagamaan Islam Syiah di Pantai Barat Sumatra." Dalam Jurnal Panggung, Vol. 23, No. 3, September.

2002. "Pertunjukan

Gandang Tambua Dalam Ritual Tabuik di Pariaman."Tesis. Yogyakarta: Universitas Gajah Mada.

Asril, Andar Indra Sastra, dan Adjuoktoza Rovylendes. 2018. Performativity of Gandang Tasa in the Mauluik Ritual in Sicincin, Pariaman, West Sumatra. Dalam Jurnal Arts And design Studies Journal, Vol 67.

Febrina, Chyntia. 2012. "Gandang Tambue dalam Upacara Maulud Nabi di Nagari Sicincin, Kecamatan 2 X 11 Enam Lingkung, Kabupaten Padangpariaman, Sumatera Barat." Skripsi Program Studi Karawitan, Fakultas Seni Pertunjukan, Institut Seni Indonesia Padangpanjang.

Merriam, Allan P. 1964. The Anthropology of Music. Northwestern University Press.

Muchtar, Asril. 2005. "Musik Nusantara Gandang Tambua." Buku ajar, Padangpanjang:

Padangpanjang. 